\title{
Література:
}

1. Кошель В.В., Павлов Р.В. Сучасні аспекти презумпції невинуватості та забезпечення доведеності вини як засади кримінального провадження. Молодий вчений» - № 11 (63) - листопад, 2018 р. C. $114-117$.

2. Лобойко Л. М. Кримінальний процес / Л. М. Лобойко : підруч. К. : Істина, 2014. $432 \mathrm{c.}$

3. Нор В.Т. Презумпція невинуватості як конституційна засада кримінального судочинства та ії застосування в практиці Європейського суду 3 прав людини. Часопис Національного університету «Острозька академія». Серія «Право». 2011. № 1(3). С. 1-24

4. Фулей Т. Презумпція невинуватості: концептуальні підходи. Засади і принципи судочинства. Слово національної школи суддів України № 1(1). 2012 С. 39-53

DOI https://doi.org/10.30525/978-9934-26-074-2-67

\section{ПРОБЛЕМНІ ПИТАННЯ ПРАВОВОГО РЕГУЛЮВАННЯ ЗАБЕЗПЕЧЕННЯ УЧАСТІ ПОНЯТИХ У КРИМІНАЛЬНОМУ ПРОВАДЖЕННІ}

\author{
Піддубна А. В. \\ кандидат юридичних наук, \\ доцент кафедри кримінального проиесу \\ та організаиії досудового слідства \\ факультету № 1 \\ Харківського національного університету внутрішніх справ \\ м. Харків, Украӥна
}

Одним із проблемних питань кримінального процесу України $є$ теоретичне переосмислення та практичне застосування процесуального інституту понятих, який було поновлено у 2012 році при прийнятті чинного КПК України. Питання статусу та залучення понятих як учасників кримінального провадження до участі у проведенні слідчих (розшукових) дій досліджували у своїх працях такі відомі вчені правознавці, як: Ю. П. Аленін, Ю. І. Азаров, В. П. Бахін, І. М. Бацька, А. Р. Бєлкіна, Р. С. Бєлкін, О. Л. Булейко, А. Ф. Волобуєв, В. І. Галаган, Ю. М. Грошевий, В. О. Коновалова, А. А. Котова, С. Д. Лукянчиков, В. Т. Маляренко, О. Р. Михайленко, В. Т. Нор, М. А. Погорецький, 
С. М. Стахівський, В. М. Тертишник, В. Ю. Шепітько, М. Є. Шумило, Ю. М. Фролов, О. В. Хітров та інші. В той же час, питання оновлення статусу понятих після 2012 року та їх участь в кримінальному провадженні концептуально не досліджувались.

У зв'язку з цим, процесуальний статус понятих в Україні розглядається як один із найбільш дискусійних напрямів у сфері кримінального процесуального права, тому що їх залучення до участі у кримінальному провадженні здійснюється 3 метою гарантування та забезпечення прав, свобод i законних інтересів учасників процесу, створення необхідних умов для забезпечення повного, швидкого та неупередженого розслідування, що $\epsilon$ безпосереднім завданням кримінального провадження (ст. 2 КПК України). Однак, законодавець, закріпивши у ч. 25 ст. 3 КПК України понятого учасником кримінального провадження та наділивши його відповідними правами [1, с. 12], не приділив достатньої уваги інституту понятого в окремому розділі КПК України, присвяченому учасникам кримінального провадження, що $\epsilon$ прогалиною чинного кримінального процесуального законодавства. Зокрема, не визначено: поняття «понятий»; його правовий статус; вік 3 якого особа може бути понятим; порядок запрошення осіб до участі у слідчих (розшукових) діях в якості понятих; обов'язок або права слідчого, дізнавача, прокурора перевіряти документи, що засвідчують особу понятого, підстави для відводу та юридичну відповідальність понятого, на відміну від інших учасників кримінального провадження.

Крім цього, виникає проблемне питання щодо законодавчого встановлення вимог до якісного складу понятих (компетентність, сумлінність, доброчесність та порядність). У правозастосовній діяльності виникають певні труднощі у слідчих і дізнавачів при запрошені осіб у якості понятих. Вказане підтверджується результатами проведеного нами опитування слідчих в ході підвищення кваліфікації. Так, 89,9\% проанкетованих нами слідчих вказали на складність запрошення громадян для участі як понятих; 91,3\% з них вказали на необхідність залучення осіб понятими у віці понад 20 років; 95,8\% зазначили про доцільність запрошення таких осіб, які проживають невіддалено від місця розташування органу досудового розслідування чи дізнання. Результати нашого дослідження підтверджено частково й дослідженнями Є. Д. Лук'янчикова та Б. Є. Лук'янчикова, згідно якого 78 \% слідчих вказали на проблеми при запрошені саме добропорядних осіб [2, с. 57-63]. Як свідчить правозастосовна діяльність, необхідність участі понятих змушує слідчих та дізнавачів запрошувати різних осіб, які, в більшості, випадково опинились на місці проведення слідчої (розшукової) дії, мешкають або працюють поруч і погодились на таке 
запрошення або особисто виявили ініціативу. Однак, існує проблематичне питання щодо: по-перше, встановлення об'єктивної незацікавленості таких осіб на момент запрошення не завжди можливо; по-друге, у слідчого, дізнавача не завжди є можливість перевірити особисті данні про таких осіб (документи, що засвідчують їх особу не завжди $\epsilon$ в наявності), що може призвести до повідомлення неправдивих даних про себе. Іншим проблемним питання $\epsilon$ труднощі запрошення понятих у нічний час, а також для участі у складних або тривалих за часом слідчих (розшукових) діях [3, с. 232], що ми підтримуємо, але вважаємо доцільним добавити й інші проблемні питання. Так, складно або взагалі неможливо залучити понятих при проведенні необхідних заходів у віддалених та важкодоступних місцях (наприклад, при проведенні огляду місця події, слідчого експерименту, огляду або обшуку місцевості, зокрема: під водою, у гірській місцевості, об'єктах, на яких відбулися техногенні аварії чи катастрофи). Водночас, слід звернути увагу й на інші обставини, які унеможливлюють участь осіб як понятих та підлягають врахуванню слідчим та дізнавачем, а саме: недосягнення особою повнолітнього віку, дієздатність, фізичний та психічний стан (алкогольне або інше сп'яніння, поганий зір або слух, явні розумові та інші відхилення або неадекватна поведінка), незнання мови, якою проводиться слідча (розшукова) дія, відсутність громадянства, віддалене місце фактичного проживання особи (чи взагалі його відсутність). Враховуючи закріплені положення у чинному КПК України в частині застосування технічних засобів фіксування відповідної слідчої (розшукової) дії (безперервний відеозапис), законодавець встановлює виняток і допускає проведення відповідних слідчих (розшукових) дій без участі понятих, якщо слідчий, дізнавач та прокурор вважатимуть це недоцільним (ч. 7 ст. 223 КПК України). Таким чином, підсумовуючи, слід зазначити, що необхідно вдосконалити положення про чинний процесуальний інститут понятих 3 врахуванням вищезазначених проблемних питань. Так, 3 метою удосконалення піднятих проблемних питань було б доцільним: по-перше, визначити та закріпити у п. 13-1 ч. 1 ст. 3 КПК України поняття «понятий», в яком зазначити що понятий це повнолітня, дієздатна фізична особа, яка не перебуває у стані алкогольного або іншого сп'яніння; не має фізичних або психічних недоліків, що перешкоджають сприйняттю змісту та результатів слідчої (розшукової) дії або заважають робити заяви і зауваження (наприклад, з вадами: німі, поганий зір та слух), яка добровільно залучається до проведення слідчої (розшукової) дії у кримінальному провадженні з метою засвідчення своїм підписом відповідності записів у протоколі виконаним діям, за якими вона спостерігала після пред'явлення уповноваженій особі документу, який 
засвідчує особу, iї громадянство, зареєстроване або фактичне місце проживання не віддалене від місця проведення досудового розслідування. По-друге, вважаємо за доцільне доповнити $\S 5$ глави 3 КПК України окремими статтями «Понятий» та «Відповідальність понятого», в яких визначити процесуальний статус понятого як учасника кримінального провадження. Зокрема, необхідно зауважити: про особу, яка може залучатися до участі в якості понятого, яка матиме права та обов'язки під час проведення слідчої (розшукової) дії (право надавати зауваження щодо відповідності записів у протоколі виконаним діям, обов'язок на пред'явлення особистих документів слідчому, дізнавачу та прокурору, інформування про особисті зв'язки та відносини з іншими учасниками кримінального провадження, зацікавленість в результатах кримінального провадження), порядок запрошення особи до участі в якості понятого, перелік слідчих (розшукових) дій під час яких участь понятих є обов'язковою, а під час яких $є$ альтернативною, відповідальність понятого у разі залишення розпочатої слідчої (розшукової) дії або за відмову без поважних причин надавати свідчення під час судового розгляду. По-третє, необхідно доповнити п. 3 ч. 1 ст. 118 та ст. 122 КПК України положеннями щодо витрат, пов'язаних із залученням потерпілого (проїзд, наймання житла та добові, у разі переїзду до іншого населеного пункту; компенсація за втрачений заробіток чи відрив від звичайних занять, тощо).

Втім, підняті питання не $є$ остаточними та підлягають окремому дослідженню або науковому вивченню. Пропоную учасникам конференції прийняти участь в обговоренні піднятих питань та наданих пропозицій.

\section{Література:}

1. Кримінальний процесуальний кодекс України: станом на 18 вересня 2020 р. Харків. Право. 2020. 428 с.

2. Лук'янчиков Є. Д., Лук'янчиков Б. Є. Законодавче регулюванння інституту понятих. Вісник кримінального судочиснтва. 2015. № 2. С. 57-63.

3. Михайлова Н.В. Проблеми участі понятих у кримінальному процесі України. Право $і$ суспільство. 2011. № 6. С. 231-233. URL: http://nbuv.gov.ua/UJRN/Pis_2011_6_48 (дата звернення: 06.04.2021). 